\title{
Critical shifts in the global tourism industry: perspectives from Africa
}

\author{
Zibanai Zhou
}

Accepted: 11 September 2020/Published online: 6 October 2020

(C) Springer Nature B.V. 2020

\begin{abstract}
The study investigates critical shifts impacting the international tourism space in contemporary times. Furthermore, the current study examines tourism policies and product development challenges faced by tourist regions as a consequence of market dynamics. Drawing upon a sample of thirty tourism experts in southern Africa, the critical shifts were identified and key among them include BRICS, terrorism, ageing population, and trophy hunting, are increasingly framing a new narrative for the future growth trajectory of the international tourism industry's value chain in the context of Africa. A conclusion is reached that to attain long term sustainable development of the sunrise multi-trillion dollar industry, it is critical that tourism operators re-set and deploy sharpened strategies which are in synch with the realities obtaining in the broader operating environment. Policy recommendations and managerial implications are proffered.
\end{abstract}

Keywords Global tourism industry · Trends and patterns · Emerging economies - Global north · Population demographics · Africa

Z. Zhou ( $\square)$

Tourism and Hospitality Management Department, Midlands State University, P. Bag 9055, Gweru, Zimbabwe

e-mail: zhouz@staff.msu.ac.zw

\section{Introduction}

Globally, tourism contributes significantly to the national economies in terms of employment creation and revenue generation (Musavengane et al. 2019; UNWTO 2018a, b). Understanding travel motivations and shifts in the global tourism marketplace is critical for unpacking future travel patterns and consumption perspectives, and also for tourist destinations to leverage on tourism spin-offs. Anton et al. (2017) observed that growing competition in the tourism landscape has resulted in destinations increasingly becoming concerned with balancing tourists with attracting new visitors.

While it is true that tourism is sensitive to violent events, political instabilities, disasters and calamities as well as economic meltdown (Alvarez and Campos 2014; Woyo 2018; Dieke 2009), it could be argued that tourism is also highly responsive to dynamics in the tourism market place. Hapairai et al. (2018) state that political crises often lead to a decline in visitorship and public and private tourism organisations should constantly adjust policies, and product offerings in tandem with market dynamics. However, research examining the fundamental shifts in the international tourism landscape is limited. Primary source markets such as the United Kingdom (UK); European Union, (EU) and North America consider emerging tourist destinations like Africa as offering alternative authentic touristic experiences as compared to over trodden traditional 
destinations. Based on this, understanding the implications of the global tourism market place fundamental shifts on emerging tourist regions such as Africa is critical for the formulation of destination- specific management strategies.

\section{Research gap}

The current study is informed by Dieke (2013) who opined that in Africa while there is a general disappointment with the economic returns from the tourism sector, there is insufficient knowledge of the market mix of international tourism, the market-driven nature of the sector, and the inability of governments to react to market changes or market signals. This is the research gap addressed by the current study. The current study therefore seeks to update and respond to these three issues at regional level in relation to Africa's tourism industry in view of tourism dynamics in the marketplace.

In addition, this study seeks to also make a contribution to the disproportionate in extant literature on the burgeoning of literature on western and mature tourism markets at the expense of Africa (Rogerson and Visser 2014a, b). The other major contribution of the current study is on the geographical ecology of tourism literature that largely remains dominated by western writers. The current study therefore ties well with Mkono (2019) 's call for more African voices on tourism issues. "A sizeable proportion of tourism research on Africa has been conducted by outsiders." (Mkono 2019, p. 3). “... Locals' opinions are often not meaningfully represented in tourism studies." Mkono 2019 , p. 3). "If tourism studies are to reflect a more balanced representation, then the lens for viewing needs to be adjusted and diversified by having more page space for Africans in scholarly works (Mkono 2019). Henceforth, the study would give a fresh African narrative in the current global tourism discourse.

In addition, Naude and Saayman (2005) and Kester (2003) observed that observed that the economic dimensions of tourism to Africa, and specifically the determinants of the demand for Africa as a tourist destination, are neglected in the economic research literature. It is on the strength of Naude and Saayman (2005)'s observed scholarly literature gap pertaining to Africa's tourism industry that the current study seeks to address. Furthermore, Christie and Crompton
(2001) bemoaned the lack of appropriate empirical research on tourism to Africa that undoubtedly contributes to the 'limited policy guidance to the sector in relation to tourism market dynamics.

In this respect, Rogerson and Visser (2011) argued that the imperative exists for strengthening the tempo of critical research on geopolitical developments, development debates, and global economic crises. In the past 2 decades, there is an expanding body of critical work on tourism in southern Africa, though still, very little is known with regard to the critical shifts in the global tourism sector. Another context underpinning this study is trophy hunting, a controversial phenomenon which has been the subject of extensive but inconclusive research from a variety of angles (Batavia et al. 2018; Batara et al. 2018; Mkono 2018). To add on, Scott et al. (2012) noted that one of the limitation of the tourism literature in Africa is that studies have tended to examine the travel and tourism industry only in terms of one element of the tourism system, usually at a nation state level, or tourism sub-sector level, rather than conducting the broader tourism system (see, Donaldson and Ferreira 2007; Mbaiwa and Stronza 2010; Buscher 2013; Kavita and Saarinen 2016; Tichaawa 2017; Hoogendorn and Fitchett 2018).

Research investigating these shifts have done so from a developed country context (see, Giraldi 2016; Debyser 2014; Maria-Irina 2017; Weston et al. 2019a) leaving a theoretical gap in the context of Africa, as an emerging destination. Understanding such global shifts is critical not only for destination managers, but also for institutional investors and public sector because it helps in terms of forecasting travel patterns, weighing investment opportunities, and budgeting. Furthermore, the constructs of terrorism, BRICs, trophy hunting and an ageing population are yet to be measured and applied simultaneously with the interconnectedness of nation states in the context of an emerging tourist region like Africa. Though there is an emerging stream of literature focusing on factors shaping international tourism future trends at the global level (UNWTO 2019a, b; OECD 2018a), there is a general absence of literature regarding the specific lynchpin variables which pertains exclusively to emerging tourist regions like Africa. Furthermore, the tourism related challenges and opportunities spawned by such fundamental variables in emerging tourist destination contexts like Africa remains mostly unknown. 


\section{Study rationale and importance}

The international tourism landscape is not only dynamic, but fraught with an environment that is constantly changing in a very unpredictable manner (Badulesani and Rusu 2009; Kyyra and Rantala 2016;UNCTD 2016). Whilst the UNWTO and practitioners acknowledge the centrality of the market dynamics in the global tourism space, there has not been a corresponding sufficient academic gaze in the current literature discourse dedicated to interrogating and unpacking such issues within the frame of Africa.

The tourism industry is considered a key growth sector in southern Africa economy. Safety and security are regarded as primary ingredients for tourism growth and destination competitiveness (Donalsdson and Ferreira 2009; Correia et al. 2013; Langfield et al. 2019); however tourism demand and factors impacting on it remain under-researched areas (Visser and Rogerson 2004). Since this study deals with the global dynamics in the areas of terrorism, BRICS, trophy hunting, and ageing population; it differs conceptually and contextually from other previous tourism development studies in tourism. This paper is therefore theoretically situated in the international tourism futures literature.

The research was inspired by the fact that the contemporary international tourism sector has matured since the 1950s. It has grown from being an exclusive preserve of advanced societies to becoming a multi-party phenomenon in which the emerging markets are now actively participating (UNWTO 2018a, b). Another motivating factor was that the industry has been traditionally dominated by the most advanced economies, especially the G7 countries, in the global north at the expense of intermediate economies, however emerging markets are encouragingly catching up (Bhatia 2001; Cooper et al. 2008).

Document analysis, archival information and expert opinions were employed to solicit for information that enriched the international tourism discourse from Africa's perspective. The study highlights the critical shifts that undergird tourism future development and growth trajectories.

\section{Research purpose and objectives}

The aim of this study is to enhance and build on (1) Christie and Crompton (2001)'s observation that there is lack of appropriate empirical research on tourism to Africa, which undoubtedly contributes to the limited policy guidance to the sector; (2) Naude and Saayman (2005)'s assertion that there is a neglect of the economic dimension of tourism to Africa; and (3) Rogerson and Visser (2011) in which they opined the existence of an imperative for strengthening the tempo of critical research on geopolitical developments, development debates and global economic crises; and (4) Dieke (2013) who stated that in Africa there is not only insufficient knowledge of the market mix of international tourism, but also the market-driven nature of the sector as well as the inability of governments to react to market changes or market signals.

The objective of this study is to understand the fundamental global shifts in the international tourism landscape with special focus on Africa. To achieve this objective, data were collected from 30 tourism experts drawn from southern Africa region. Specifically, this study seeks to answer the following research questions: (1) Why should emerging tourist regions like Africa be concerned with dynamics on the broader international tourism landscape? Of these factors, which ones significantly predict the future growth trajectories of the tourism industry in African context? Which specific tourism market shifts have impacted on Africa's tourism sector? (2) What challenges and opportunities do emerging tourist destinations face in the advent of these global shifts? What challenges and implications do these shifts pose on Africa's tourism product offering, marketing strategies and planning for her tourism sector. In addressing these research questions, this study advances the understanding of the long term consequences of the global shifts on Africa's travel and tourism landscape. This study also adds to the debate focusing on travel motivations, trophy hunting (Baker 2010) crises (Steiner 2017; AlShorman et al. 2016), and mitigation strategies from a context-specific emerging tourist destination. The results of the survey can meaningfully inform the formulation of marketing messages aimed at repositioning Africa, thus making it even a more appealing tourist destination in spite of headwinds in the marketplace. In what way can Africa better prepare and anticipate the impacts of these shifts on custom, turn over, sales, investment etc. 


\section{Paper structure}

The remaining sections are structured as follows: the next section briefly reviews key themes in relevant existing studies highlighting the sector's economic significance at global level. This is followed by a brief description of the data and the empirical methodology. The analyses section provides a discussion of the empirical results using the content analysis highlighting the multi-faceted nature of tourism market dynamics. The final section provides overall conclusion and recommendations.

\section{Literature review}

Current state of tourism research in Africa:

a regional and international context

Several studies have examined variables impacting international tourism at global level in different regional contexts, for example, tourism senior market (Naude and Saayman 2005; Alen et al. 2015); BRICs (Pop 2014; Abdou and Adawy 2018) using a number of relationships including data panel analysis, time series, arrivals and receipts; direction flows and distribution. However, studies examining the constructs of BRICs, terrorism, senior tourism market (ageing population demography), and trophy hunting controversy, from the African region perspective are limited. For example, existing studies have only investigated international tourism trends from advanced societies' contexts; cases in point include Maria-Irina (2017), Debyser (2014), Weston et al. (2019a) among others. Likewise, Rogerson and Visser (2011) argued for the continued need to understand the market dynamics fuelling tourism development trajectories in different tourist destination contexts. Additionally, previous studies that focused on tourism development in African tourist destinations have not only been restricted to a specific country or sub-region of continental Africa, but also limited in scope as they largely focused on specific segments and certain clusters of the tourism sector such as mega events, wildlife (Saarinen 2018), tourism and poverty alleviation (Spenceley and Meyer 2017), urban tourism (Rogerson 2013), ecotourism (Mbaiwa 2008) among others. While these studies provide in-depth analyses and insight into Africa's tourism, there has not been an attempt to engage in other evolving issues with the potential to change the complexion of the region's tourism sector.

On the international scale, there has been a sustained research on issues influencing the unpredictable dynamics of the international tourism ecosystem that hogged the global limelight, ranging from the September 11, 2001 terrorist attacks on the US, Tsunami; SARs epidemic in Asia (Gaetano 2009; Schuurman 2019; Qui et al. 2018; Zeng et al. 2005; Bongkosh 2006; Tang et al. 2020); Asian financial crisis, the current Covid-2019 virus, Ebola outbreak in western Africa (Song and Lin 2010; Wang 2009; Gossling et al. 2020; Al-Tawfiqef et al. 2014; Maphanga and Henama 2019; Kongoley 2015); political conflicts in the Middle east; Icelandic ashes, the disappearance of Malaysian airplane (Al-Shorman et al. 2016; Steiner 2017; Benediktsson et al. 2011; Heimisdottir et al. 2019; Weng 2014; Fan et al. 2019); CITES's trophy hunting ban, as well as climate change induced extreme weather patterns like hurricanes, cyclones and heat waves (Prideaux et al. 2009; Njerekai and Mabika 2016; Baker 2010; Pandy 2017; Moore 2010). Whilst acknowledging the diverse and richness of the current international tourism body of literature, the current study argues that very little attempts have been made to explore the policy and product development implications of the constructs of BRICS, terrorism, ageing population and trophy hunting in the context of Africa. Perspectives on these evolving issues from emerging tourist destinations contexts seem neglected in the academic gaze, yet in contemporary times these are the issues increasingly influencing dynamics in the tourism space.

None the less studies offering a regional perspective from emerging tourist destination context are limited; with existing studies only investigating specific segments of the tourism industry in Africa, for example, township tourism (Boyens 2010); conference tourism (Donaldson 2013); communities and trans-frontier parks (Ferreira 2006), and green guest houses (Hoogendorn et al. 2015), with very little attempt to relate these to market shifts.

Though there is a substantial research on tourism, the tourism marketplace, remains dynamic. Debyser (2014) analysed the challenges and policy responses to the tourism sector by the EU, whilst Tolkach et al. (2016) explored current and emerging tourism trends in the Asia Pacific region through a content analysis. 
Tolkach et al. (2016) study found that economic growth, favourable political environment and improved infrastructure were sustaining continual growth of the sector in the region. Furthermore, Maria-Irina (2017) examined tourism in the new member states of the European Union in which the focus was on the importance of tourism, factors and trends that affect the industry within the EU community. Still, Weston et al. (2019b) provided an overview of the current state of affairs in European tourism, considering the latest developments, identifying future challenges and emerging opportunities. The study established that changes in tourist behaviour and generational issues were significant challenges. Even though there is a burgeoning tourism studies in the African contexts for the past 2 decades, for example, Ferreira (2004), Donaldson and Ferreira (2007), Ferreira et al. (2007), Booyens and Visser (2010), Rogerson (2011), Zhou (2014), Scholtz and Slabbert (2016) and Tichaawa (2017); still these researches apart from being disproportionately too low to tourism researches in Europe and The Americas, they have been consistently oblivious of the quartet of BRICS, trophy hunting, ageing population and terrorism as critical shifts in the tourism landscape, hence leaving a theoretical gap in emerging tourist regions like Africa. To put the issue into perspective, studies examining dynamics in the international tourism industry since 1950 in the context of Africa are limited. A case in point is the study by Signe (2018) who examined Africa's tourism potential, renewed trends, key drivers, opportunities and strategies. The study found that there was huge potential due to the continent's richness in natural resources and cultural heritage; and that west African countries had introduced a visa policy to enable free movement of people across member states. Furthermore, the study established that tourism was important to Africa as it was driving economic growth and job creation, infrastructure development, generating foreign exchange. Globalisation was the key driver of tourism. Challenges of poor infrastructure and weak institutions were cited, whilst opportunities were that Africa was the best candidate for investment. Similarly, Diakite et al. (2020)'s study was country-specific. They examined tourism trends, opportunities and challenges in Guinea in which it was established that Ebola was a major challenge. In addition, Jaensson (2014) examined potential for tourism development in sub-Saharan
Africa in cooperation with Sweden. The study results showed that the sector is important in poverty reduction, foreign exchange earnings, employment and economic growth.

Still, Zhou (2014) analysed recent trends and future prospects of tourism in southern Africa sub-region. The study's focus was on tourism development and growth at sub-regional level, and the study found that the need for economic diversity, job creation, foreign currency generation were factors motivating southern Africa countries to develop the tourism sector. Hosting of mega events, establishment of nature parks and aggressive marketing campaigns were identified as key elements allowing for the resurgence of tourist arrivals in the sub-region. Dieke (2013) examined a production-nexus of tourism in sub-Saharan Africa. Dieke (2020) analysed tourism issues and prospects in Africa. The study focused on the current state of tourism to and within Africa, highlighting key themes and issues that confront the industry across the continent. The results of the study showed that human resources have had consequences for the sector, resulting in the further marginalisation of Africa in the global pleasure periphery. Taken together, these studies revealed that understanding the dynamics in the international tourism arena is critical for destination managers because it helps in terms of forecasting travel patterns, demand for tourism products, growth projections and investing in new product development, investment into new markets, trends among a host of others. Furthermore, from the analysis of previous studies it seems researches making a direct application of these critical shifts to a particular or specific emerging tourism region like Africa are lacking. Though there is an emerging stream of literature focusing on various facets of Africa's tourism industry, (see Ferreira 2006; Boyens 2010; Slabbert and De Plussis 2013; Donaldson 2013; Rogerson 2014; Tichaawa 2017; Chiutsi and Saarinen 2017; Musavengane 2018; Mbaiwa 2018), there is a general paucity of literature regarding how the dynamics obtaining on the broader international tourism arena would mean for Africa's tourism industry and how the continent should respond to such critical shifts at operational and policy making level, tactically and strategically. It is a compelling case to investigate how such dynamics inform tourism policy formulation, inform investment options into product development, inform investment into new 
markets, and inform re-calibration of marketing strategies; which in the context of Africa remain mostly unknown.

Alvarez and Campos (2014) and Woyo (2018) posit that tourism is sensitive to political, economic, ecological, technological, legal and socio-economic environment. However, research examining such critical shifts in the broader global tourism environment and their attendant implications to emerging tourist regions like Africa is limited.

Overview of international tourism and its socioeconomic significance

The post world war two (WWII), boom factors chiefly the advent of jet engine, political peace and economic stability, dual family income, inclusive tours, coupled with ICTs and education, generally laid the ground work for the growth and development of the tourism industry (Bhatia 2001; Boniface and Cooper 2001; Lockwood and Medlick 2001). However, whilst these factors are still relevant, the tourism industry has mutated as new variables evolve, presenting a new set of opportunities and challenges for the tourism industry requiring a different approach from tourist destinations. International tourist arrivals world-wide grew over 1.4 billion in 2018, 1.5 billion in 2019 and most likely the threshold of 1.8 billion travellers is now likely to be exceeded in advance of 2030 (OECD 2020). Globally, international travel receipts reached $\$ 146.2$ billion in 2018 , and globally expenditures on travel have more than tripled since the turn of the century, rising to 1.5 trillion in 2018 (UNWTO 2019b, 2020).

Tourism is crucial to the global economy, and is regarded as a trillion dollar industry, contributing immensely to GDP, as well as employing one in every 11 people (UNWTO 2018a, b). Tourism contributes to the world economy GDP directly and indirectly through provision of full time jobs, it has a multiplier effect on down and upstream economic sub-sectors (WTTC 2017; Zhou 2019; Musavengane 2018; Mbaiwa et al. 2019; Saarinen et al. 2009; Nyahunzvi 2015). The recent developments in the broader global economic environment underpinned by the emergence of BRICS, an ageing population demographic, calls for CITES reform cum ban on trophy hunting, and the scourge of terrorism are collectively recognised by the academia, tourism fraternity and policy makers as shaping the global tourism growth agenda and its development trajectory dynamics in the twenty-first century. Despite the severity and weight of these evolving issues, the global tourism industry is poised to grow in stature. While this is the case, there seems to be limited academic rigour on such phenomena, given that the available scholarship on global tourism industry dimension has not adequately explored the extent to which individual factors like the BRICS, population demographics, trophy hunting debate are shaping and influencing the global tourism industry growth trajectory.

The tourism industry is one of the fastest growing sectors of the global economy, and the sector is a benefactor of the globalisation process. In 1950 there were 25 million international tourists arrivals, in 2000 there were 1 billion tourists, in 2020 it is envisaged that 1.6 billion international tourists would engage in touristic activities, and further still in 2030 the figure is forecast to hit the 1.8 billion (UNWTO 2010, 2019a, b). However, despite these impressive aggregate arrivals figure, the sector has to grapple with a milieu of opportunities and threats born out of the ever evolving tourism market place.

On the employment front, tourism is extremely labour intensive and a significant source of direct, indirect and induced employment. It is among the world's top creators of jobs requiring varying degrees of skills and allow for quick entry into the workforce for youths, women and migrant workers and the UNTWO indicated that the tourism sector provided 296 million jobs in 2019 (WTTC 2018; OECD 2018b; UNWTO 2019a, b). With over 1.2 billion people world-wide crossing international borders each year, tourism is increasingly becoming a major source of growth, employment and income for many countries including many of the world's developing countries. Tourism has the potential to contribute to all of the sustainable development goals (SDGs) found within the 2030 Agenda for Sustainable Development, including SDG 8 on inclusive and sustainable economic growth, SDG 11 on cities and human settlements, SDG 12 on sustainable consumption and production. This underlines the need to rightly place tourism as one of the key pillars of socio-economic development.

The World Bank (2014) and UNWTO (2018a, b) posit that tourism will be one of the main drivers of economic growth in Africa over the next decade. An 
increasing number of countries, for example, South Africa, Kenya and Rwanda henceforth, have made tourism a central pillar of their economic development and reform program, and have made significant economic strides using tourism as a plank to boost their economies. Page (2018) and Coulibary (2018) concurred that tourism is an escalator of development. However, in order for Africa to reap tourism benefits, the region has to align its tourism offerings to marketplace dynamics.

Despite Africa's documented perennial challenges, curtailing the growth and expansion of the tourism industry, that encompasses infrastructure underdevelopment, access issues, lack of direct flights, little appropriate promotional marketing strategies and investment budgets, portrayal of Africa as a land of war, disease, poverty, hunger, anguish and desperation by foreign mainstream media, 67 million tourists visited the region in the region, generating $\$ 194.2$ billion worth of revenue (Diakite et al. 2020).

Tourism in Africa: socio-economic significance on African economies

Henceforth, tourism is a powerful vehicle for economic growth and job creation all over the world. Tourism's main comparative advantage over other sectors is that visitor expenditures have a "flowthrough" or catalytic effect across the economy in terms of product and employment creation (Christie et al. 2013; Schubert et al. 2011). Given the multisectoral nature of tourism, its success is dependent upon the external and internal dynamics on the environment. The potential for tourism growth in Africa is significant, anchored not only on the region's abundant pristine wildlife coupled with expansive beaches, but also on its cultural heritage. Continental Africa is poised to realise $\$ 262$ billion in revenue from 1 billion people travelling internationally. At first glance, it may appear that its smooth sailing for Africa, however, on closer inspection, such a bright future projection is made without taking into account the critical shifts panning out in the tourism market place. Africa's adaptive capacity in relation to the risks and opportunities posed by market dynamics will ensure the success of its tourism sector. The fact that the BRICS, ageing population, terrorism and trophy hunting issues are taking root in the marketplace it is about time that emerging tourist destinations tourism starts a serious conversation to establish the implications of these dynamics on the tourism system.

It is no doubt that Africa has had an impressive average growth rate of her travel and tourism, which trends have continued into the twenty-first century, bolstered by a period of impressive economic growth and improvements in political stability and opportunities across the continent. The African Development Bank (AfDB) indicated that in 2015, Africa recorded 62.5 million visitors, contributed 9.1 million jobs directly and generated $\$ 39.2$ billion international tourism receipts (AfDB 2016, p. 4). Looking into the future, there is substantial room for growth in Africa's travel and tourism market, particularly in light of current sectoral growth patterns, as international tourists are increasingly interested in developing countries as travel destinations, provide the region properly align its tourism sector to dynamics obtaining in the marketplace.

Tourism is a major global economic sector that is undergoing tremendous growth in emerging economies and is often touted as salient for the development and poverty alleviation in developing countries (Scott et al. 2012).

Tourism has been embraced largely due to its employment and foreign currency generative capacity, as it continues to make a substantial contribution to the economies of many countries around the world (Zhou 2014; Mkono et al. 2020). With the exception of 2020, each year, the tourism industry has outrun projected international tourist arrivals riding on the back of liberalisation of the aerospace, globalisation, and rising income levels. It is forecast that if the current momentum is maintained, international tourist arrivals are expected to reach 1.8 billion by 2030 (UNWTO 2020). Tourism is an important economic sector to many African economies in terms of its contribution to gross domestic product (GDP), employment and trade (UNCTD 2017). At a time when the region is building its productive capacities, consolidating regional integration and pursuing economic diversification, tourism in Africa continues to grow. Apart from stimulating employment creation and enticing investment, tourism also contributes towards the preservation of ecosystems and biodiversity.

At continental level, the African Union's Agenda 2063 recognise tourism's importance in driving Africa's socio- economic development and structural transformation through job creation. The Economic 
Development in Africa Report (2017) reported that tourism can be an engine for inclusive growth and economic development and that it can complement development strategies aimed at fostering economic diversification and structural transformation within the right policy context. However, conspicuously missing in the report is any reference to terrorism, ageing population, trophy hunting, and BRICS, and the extent to which they threaten the envisaged economic gains. To achieve this Africa must be cognisant of changes taking place in the global tourism market place. Tourism marketplace dynamics provide greater scope for the region to boost international travel into Africa, leveraging on Africa's comparative advantage of its renowned tourism resource base. Market dynamics will inevitably alter the competitiveness of tourist destinations as well as the suitability of major tourism market segments. It is evident that all tourist destinations will need to adapt to market dynamics, whether to minimise risks or to capitalise on new opportunities associated with the constructs of BRICS, terrorism, trophy hunting and ageing population.

\section{Methodology}

Data were gathered through document analysis, combing archival information and expert opinions canvassed from key informants drawn from the broad travel and tourism industry who were knowledgeable about the dynamics and trends of the international tourism industry from Africa's perspective. Regional market shares, and tourist arrivals from 1950 to 2020 , UNWTO forecasts and projections were employed.

Key interview informants were qualified as tourism experts on the basis of their extensive working experience directly in various sub-sectors of the tourism industry at regional and international level, that is, hotels, tour operations, conventions, NTO as regional and international tourism markets, tourism attachés in charge of overseas tourism markets, tourism market development, planning and forecasting. Informants' intimate knowledge on international tourism and market dynamics coupled with extensive working experience in the hospitality and tourism sector earned them the expert status. In order to participate in the study, respondents had to have over 20 years working experience in the tourism sector at senior management level in the marketing department in charge of regional and overseas tourism markets. To widen the pool of informants, the study included responses of tourism experts including representatives from government, international organisations and other tourism industry related government departments selected through snowball technique. This was also supported by a review of recent literature and data.

Resultantly, a total of 20 interviews were administered out of a total population of 30 potential informants (Krejciie and Morgan 1970). A pilot study was done before the actual data collection to ensure the comprehensiveness, readability and clarity.

In-depth interviews were conducted with 25 purposively sampled respondents. Interview session lasted an average of $30 \mathrm{~min}$. Interviews were discontinued after data saturation was reached. The study was based on predominantly a series of open-ended, semi-structured interviews conducted with ten female, and fifteen males purposively selected from tourism representative bodies. Semi-structured interviews were chosen because they allowed the researcher to probe for additional information and to seek clarification. The above is in line with the assertion that semistructured interviews offer insights "into respondents' memories and explanations of why things have come to be what they are, as well as descriptions of current problems and aspirations" (Stake and Torrance 2005, p. 33). The interviews that were conducted were restricted to people who gave their informed consent and each interview lasted on average $30 \mathrm{~min}$. Items on the interview schedule were informed by literature and prior studies related to tourism growth in other touristic regions. The research participants were asked a broad range of questions in order to gain an understanding of the interplay between the global tourism industry and dynamics in the broader global operating environment in the context of Africa. The line of questioning explored, key variables driving tourism at global and regional level, critical shifts in the tourism market place influencing tourism development, tourist regions' responsive strategies to market dynamics, implications of contemporary market dynamics to emerging tourist destinations among other aspects. Data were recorded manually (Saldana 2013). The interpretation and analysis of the qualitative materials was an on-going process that proved inseparable from the field work. In the field, after each interview, the data was analysed to inform subsequent 
interviews and to capture preliminary emergent themes as recommended by Mertens (2005). After fieldwork, the interview material was later, thematically analysed to reveal emergent themes, following Miles et al (2013) and Veal's (2006) guidelines. In line with qualitative research, interviews were discontinued when theoretical saturation or data redundancy was reached (Jennings 2005); in this case five out of the 25 interviews held contained no new themes. The next section provides a detailed and concurrent presentation and discussion of the dominant themes that emerged during the interactions with the research participants. Four themes were identified in the analysis of the qualitative materials that were obtained from the interviews. These were BRICS, senior tourism market, CITES' trophy hunting debate, and the scourge of terrorism. Each one of the five themes is discussed below.

\section{Results and discussion}

Recurrent themes which emerged from respondents' narratives were grouped into five key themes, which were; BRICS, ageing tourism market, trophy hunting and terrorism.

\section{Formation of BRICS economic grouping}

A number of respondents found that the BRICs economic grouping was indeed a game changer in the tourism marketplace. BRICS being a post 2000 phenomenon was set to establish a new economic world order, competing with the G7 countries which traditionally dominated the tourism sector. In particular, informants described BRICS as revolutionary in tilting the balance of economic prowess in favour of the developing countries. This is a critical milestone in the historical development of the tourism industry in the sense that for the first time the global south is playing a significant role in the global tourism affairs. In light of such market realities and as a way of going forward it implies Africa should now improve its tourism infrastructure to match world class standards ahead of increased tourists from BRICS. Africa's tourism product should also be now tailor made to accommodate new a new market with a new set of preferences, tastes and travel habits/behaviour different from the traditional western markets. This echoes the sentiments of UNWTO (2018a, b) and Znojek (2012) that going forward emerging economies will drive the key economic sectors at global level, including tourism. To illustrate, respondents pointed out that China, India, Brazil, Russia and South Africa are increasingly emerging as key tourism source markets ahead of the traditional markets of western.

In contemporary times, countries from the global south, buoyed by an uptick in per capita income are poised to become leading contenders for the first time in international tourism growth matrix despite being insignificant in the broader global tourism industry in the 1950 s.

Another insight revealed by respondents was that since WWII, the global financial sphere was been dominated by the Bretton-woods institutions, however, this was changing with the rise of the Asian Tigers, coupled with rapid economic transformation in the emerging markets fronted by BRICS. Tourism is driven by an economic boom, a characteristic feature punctuating the BRICS. Brazil of South America, Russia of Eastern Europe, India and China of Asia Pacific, and South Africa from southern Africa constitute the BRICS gamut. On the horizon, the five-nation state grouping is determined to set up a multilateral financial institution modelled alongside the century old International Monetary Fund (IMF) and World Bank (WB) as a way of disrupting the status quo in the global financial services market systems. The implications of the BRICS bank after its eventual full consummation would be the source of funding of tourism developmental projects for the emerging markets. Such projects would be prioritised in terms of funding without the bureaucracy and exclusionary tendencies synonymous with the IMF and WB. It also imply that nation states from the global South would easily access loans as seed capital to shore up and stimulate economic development which will later on spur economic prosperity and eventually boost tourism. The birth of BRICS is changing the face of the international tourism in much the same way as the boom factors of the 1950s-60s did through enhanced tourism access, free flow of international tourism traffic and capital without restrictions, enticing of FDI, and boosting of demand in favour of the emerging markets.

Favourable implications on Africa are the characteristic features punctuating the BRICs which support tourism, that is, fastest growing economies, rapidly 
expanding middle classes and promising domestic markets, as well as the potential to overtake the G7 as the world's best performing economies by 2040 (Pop 2014). Given the positive relationship between economic performance and tourism, this would mean that a huge boost for the BRICS nation state's respective tourism industries with a potential spill over to the rest of African region. The emerging markets of the BRICS countries have long been highlighted as the future power houses of the travel and tourism industry. Abdou and Adawy (2018) contend that BRICS countries are the leading economies in the world as they are expected to cause a global economic shift and have power more than Europe economies and US in the near future.

Informants were excited by prospects of China and India morphing into citadels of commerce at global level. The BRICS premise is very significant to the tourism industry of emerging countries in several ways. China and India are set to mutate into hubs of manufactured goods and services globally, while Brazil and Russia will become leading suppliers of raw material. The BRICS is set to become the seat of influence on tourism affairs, from being the leading global tourism market, leading tourist destination, leading recipient of tourism related FDI unlike the period in the early 1960s. This finding is in line with projections made by the IMF and WB that in future China and India will become global centres of commerce and trade. One official had this to say:

Certainly, BRICS will upset the applecart, already there is a seismic shift in the tourism marketplace, where we see traditional tourist destinations becoming less and less popular, whilst emerging markets are shining

Currently, BRICS account for more than $40 \%$ of the world's population, over $50 \%$ of world economic growth, 53\% of world foreign investment (Zhao 2011; Znojek 2012), and has been deemed as a platform for the emerging economies to share a stronger voice on the international stage. To be specific, Brazil occupies a prominent place in world affairs, and is one of the world's ten biggest economies, India is an emerging global power, South Africa is equally a regional power with global aspirations and has taken a more assertive continental role. It is Africa's largest economy and regarded as a doyen of democracy, whilst at the same time it is a key player in the region's stability (Carothers and Young 2011).

BRICS' long haul objective is to accelerate the shift towards a multi-polar international order and to gain an adequate presence for emerging economies in reformed global institutions. Unlike before when the global tourism industry was dominated by the $\mathrm{G} 7$ countries, which are essentially proxies from advanced economies, the emerging markets of the BRICS have thus been regarded as the future powerhouses of the travel and tourism industry as evidenced by the increasing trend where upon the BRICS feature prominently in the World Travel Market Industry Report (World Travel Market 2012).

On inbound tourism China is increasingly becoming a leading tourist destination at global level, Brazil at second place challenging traditional leaders like France, Spain, and the US. To its credit, BRICS is well endowed with natural and cultural tourism resources, massive infrastructural developments in the way of air and ground transport, protected land areas, and richest fauna in the world. This gives it comparative advantage over the traditional G7 countries. In essence, this is driving the global tourism trends to gravitate towards the emerging markets as opposed to the traditional western markets.

Africa should take a cue on how BRICS is also shaping a new narrative in the event tourism space. The increasing importance of mega events particularly sporting events such as the Olympics and the FIFA world cups provide a window of opportunity for highly significant upgrades in infrastructures, human resources, products and quality. South Africa's 2010 FIFA world cup was a resounding success, Olympics Winter Games in Russia Federation and FIFA world cup 2018 in Russia, FIFA world cup in 2014 in Brazil and the Olympics Summer Games of 2016 helped putting the BRICS on the global tourism map. There is no doubt that the growth of the global tourism industry is being driven by emerging economies, that is, BRICS. The present dynamics confirm that unlike in the twentieth century where economic growth was mainly driven by the developed world, in the twentyfirst century, the growth engine has relocated to the emerging and developing markets, particularly the BRICS.

As per capita incomes increase, the services sector grows relative to the other sectors of the economy, and this dynamic is important as the BRICS countries are 
planning to go from middle to high income status. Resultantly, many countries world-wide are now actively courting tourist arrivals from the BRICS in particular China. Given its large population, and the fact that a growing percentage of people can now afford, both in terms of time and money to travel overseas has had a major impact on the global tourist market. Globally, on the economic and tourism front, there is a scramble for the BRICS as they represent tomorrow's tourism sunrise economy. There is huge appetite world-wide to invest in the BRICS' tourism sector, which in itself is an endorsement in terms of the shift of balance of power in tourism demand generating markets. The BRICS have indeed become a force to reckon with in international tourism affairs in the period post WWII just like the G7 countries. China and India, for example, buoyed by the population demographic factor are set to tilt the balance of power towards the Asia-Pacific as both a generator and recipient of outbound and inbound international tourism traffic. As such, BRICS have emerged as an important player in the global economic sectors, tourism included, with its services export growing faster than the developed countries. At the same time BRICS are generating an increasing number of tourists as per capita income rise and a relatively big share of this increase would be spent on tourism. In this milieu, the over trodden global north tourist destinations have now matured hence the focus has turned on exotic tourist destinations which are far flung from the beaten track.

\section{Ageing tourism market}

The majority of the respondents suggested that the elderly population presents a market of particular relevance to a large number of industries for its high purchasing power, comparatively higher than younger groups, more so to the tourism industry. It was apparent from the response that the tourism sector was emerging as one of the biggest beneficiaries of the ageing process as a result of changes in the lifestyle of the population. This finding conforms to Alen et al. (2015) and Cooper et al. (2007) who similarly established that the ageing baby boom generation was slowly becoming one of the most important markets in the tourism context. Indeed, the ageing of the baby boom generation marks an important milestone in the development history of the tourism sector in light of their purchasing power. Schroder and Widman (2007) deemed the senior tourism market demographic change as one of the biggest growth and most important markets in the tourism industry, turning it into the engine of growth for tourism. This is in consonance with the UNWTO $(2018 \mathrm{a}, \mathrm{b})$ 's prediction that by 2050 there will be more than 2 billion international travellers aged 60 and above compared to 593 million in 1999 (Patterson 2006). Such demographic shifts will affect the structure of tourism supply and demand at regional level. The implication on Africa about the increasingly ageing population is that market tastes and vacation habits will change. The senior market clientele is experienced, more discerning and high spenders. This corroborates Glover and Prideaux (2009)'s observation that population ageing affects the future choice of tourism activities and destinations, and ultimately future tourism growth projections like trends, patterns and traffic. As the global tourism market gravitates towards the senior market, so does its tastes, preferences and holiday patterns. This is in synch with Weaver and Oppermann (2000) and Salt (2003) who support the view that demand for tourism products and experiences change with age. The senior tourism market is keen to travel to exotic tourist destinations like Africa calling for an overhaul of Africa's tourism product. Individual factors such as family status, employment, education, health status, travel experience and generational values change with age, henceforth tourist destinations have to pay particular attention to these and adjust product offerings accordingly (Glover and Prideaux 2000).

An ageing population implies that the demand for authentic tourism products and experiences most in emerging regions like Africa aimed at the senior tourism market or older population is likely to increase both in actual number and in proportion of all holidays as the number of older people grows. The senior tourism market, given its old age, takes more leisure trips more frequently courtesy of the availability of time and higher discretionary income. It is therefore instructive that if emerging tourist destinations are to remain competitive and successful they need to be aware of the differences that may be apparent in the demand profiles of specific generation gaps. From Africa's perspective, the battle for the competitiveness and growth of the global tourism market share will be fought and won on the basis of them being capable to 
appeal to multi-generation markets. Tourist destinations in the global tourism industry vigilant to tourism market shift on tourism demand based on population demographics are poised to reap the benefits.

Prideaux et al. (2000) posit that the inability of tourist destinations from recalibrating current range of tourism products and services to reflect the aspirations and consumption patterns of senior market may result in a slow decline in visitor numbers in the coming years. Ideally, tourist destinations world- wide recognise that a change in demand is underway hence the need to start working on modifying the tourism product that resonates with an ageing population. In short, tourism demand would be a function of population demographics. An understanding of where the world and tourism market is heading is crucial for identifying opportunities that are brought about by that change.

Embedded in ageing are health issues such as hypertension, obesity, and heart diseases which increase in prevalence along with age. Ageing population equally has a business and financial dimension, that is, the elderly are better educated and wealthier than previous generations (Callister 2006). The elderly tourism market is keen to give back to the community or cultures they visit, they therefore combine tourism with volunteer work, aptly labelled as voluntourism (Furlong 2006; Thornhill and Martin 2006). The tourism industry must ensure that appropriate facilities are available to meet the needs of these consumers. Whilst developing countries are still comparatively characterised by young population, industrialised countries are confronted with an ageing population, and low birth rates (UN 2011; Goldin 2010).

\section{CITES' trophy hunting debate}

Informants were unanimous that the tourism industry experienced an unprecedented poaching and decimation of wildlife on an industrial scale in the period post WWII, which was a cause of concern as it sends shockwaves on the tourism marketplace. The situation is grim in emerging markets mostly Africa.

Respondents were unanimous that the tide needed to be tamed as it was threatening the very foundation of tourism hence putting the future of the tourism sector at stake. The above sad state of affairs in emerging tourist regions fed into a post WWII tension increasingly mounting between the global south and global north on the emotive issue of trophy hunting, which falls under the auspices of CITES. Another respondent seemed to indicate that trophy hunting was more relevant to Africa given that the region's tourism industry is anchored on wildlife. It was interesting to note that the draw card of emerging markets' tourism industry was now at the centre of the contemporary global stand-off pitting the global north against the global south. Perspectives from Africa show that the region is much concerned about the power play on over-regulation, embargoing trophy hunting, and preservation of such wildlife in light of limited budgets characterising most African countries. Ironically the consumers of Africa's trophy hunting products are tourists who come from the global north who are lobbying for a total ban. This creates an awkward position for Africa.

What this implies to Africa is that the region has to adjust and endeavour to co-exist with the global tourism family in the sense that if the region pulls out of CITES it risks a serious backlash from partakers of wildlife experiences. The current state of the tourism industry has been predicated on the huge wildlife resource base sprinkled across the breadth and length of tourist regions. However, post WWII upheavals in the wildlife sector characterised by increased poaching, alienation of local communities' rights to the utilisation of wildlife resources, blanket imposition of a moratorium on trophy hunting and a plethora of other issues are set to continue fuelling a bruising contestation regarding the sustainable use of wildlife in the broader context of tourism development (Mkono 2018). Consensus on how the contentious and divisive trophy hunting issue should be handled to the full satisfaction of all CITES members and secure the sustainable future development of the tourism industry is still a challenge. Whilst emerging tourist regions like Africa feel hard done by CITES stance, with sentiments indicating that the issue seriously undermine wildlife conservation efforts, and ultimately the tourism experiences in nature parks and conservancies, it is critical to have a holistically approach on the issue.

Indeed, exotic tourism regions like Africa are well known for their pristine wildlife sanctuaries where tourists encounter with nature. World-wide the tourism phenomenon has been driven by flora and fauna, however given the increasing rate at which poaching and depletion of wildlife resources are happening, 
CITES justifiably came on the scene to regulate the use of wildlife within the tenets of sustainable tourism. To this effect CITES outlawed trophy hunting which arguably used to generate funds for the conservation and management of wildlife resources especially in emerging markets like Africa and Asia-Pacific. Subsequently, there has been a raging debate on trophy hunting which has divided global opinion. The future of the global tourism hinges on the reform of CITES's stance on trophy hunting. Arguments proffered mostly by the emerging markets revolve around the urgent for a review of trophy hunting ban to avoid what they claim an impending wildlife catastrophe since the wildlife population has ballooned to unsustainable levels as a result of a moratorium imposed on trophy hunting. Yet on the other side of the spectrum, the global north is advancing the argument that a ban on trophy hunting should remain in force into the foreseeable future. The stalemate would definitely impact on global tourism trends and patterns, more so on Africa in a negative way.

Trophy hunting has thus become a delicate matter in the international tourism discourse since it can rally nation states towards the conservation of wildlife resources which are the bedrock of the tourism sector. Trophy hunting is a topical issue in international tourism affairs, so much that a divided global family of nations on it foments disillusionment, smacks fragmented approaches in fighting the poaching scourge and eventually lead to the decimation or a complete loss of the wildlife resource which is a key driver of the sector. Global consensus on trophy hunting and the way forward between the global south and north will define the new course of tourism growth in the foreseeable future. Without wildlife resources there is no tourism sector to talk about hence this is critical at this juncture. Poaching remains the greatest threat to the integrity of natural sites globally.

Terrorism and interconnectedness of the globe

Results showed that in the contemporary globalised village, emerging tourist destinations like Africa are no longer immune to the scourge of terrorism that traditionally was more pronounced in the western countries and North America. However, respondents indicated that Africa is increasingly becoming a target of terrorist, citing an example of Kenya in East Africa; Tunisia in North Africa. What it therefore implies is that it can no longer be business as usual but in essence emerging markets should start investing in ports of entry screening technologies and reviewing visa regimes with a view of strengthening security protocols.

Safety of international tourists is of paramount importance, hence this should be guaranteed. Future global tourism trends will be defined and influenced by the safety records of tourist regions, as well as their response systems to terrorist attacks. This finding corroborates Paraskevasa and Arendell (2007), Hoffman (1998) and Chalk (1997) who established that tourists rank safety and security highly when choosing vacation holiday. Given the ever increasing rate at which conflicts are erupting in emerging markets in particular and at global level in general as a result of the increasing chasm between the rich and poor, it is important that tourist regions reflect deeply on terrorism threats and the instability it poses to the development and growth of the international tourism industry. It is apparent that transnational tourism organisation like the UNWTO and WTTC quickly issue out advisories dissuading potential tourists from visiting destinations prone to terrorist activities, as they value the safety and security of vacationers. While at face value this may sound akin to destination de-marketing, tourists' safety and security is of utmost priority. The burden lies with destinations to ensure the safety of visitors. Peace and security at tourist destinations would remain the single most important factor to guide tourism development going into the future. Globally, as revealed above, the security situation remains precarious, impacting negatively on tourism growth projections.

With such a remarkable shift, it therefore calls for a coordinated global approach in the fight against terrorism, a serious threat to tourism, which has become a global menace embedded in a modern society characterised by extremes of rich and poor in both the developed and the underdeveloped countries. Terrorism has been targeting popular tourism spaces, and given the lack lustre security systems in place in emerging markets there is need for collaborative efforts to tame the wave of terrorism in order to create a better world where tourism can thrive. Africa should realise that the interconnectedness of nation states celebrated under the auspices of a global village has opened up countries to global risks and vulnerabilities like terrorism, contagious diseases, for example, Covd-19 virus. This has huge implication on tourist 
regions' immigration and border control issues, visa regimes, health issues with far reaching consequences for Africa's tourism sector. Taken together, these issues are at the centre of curtailing the free flow of tourists. Emerging tourist destinations are in a dilemma on whether they should opt for a protectionist-cautious stance in terms of the free flow of people or a more liberal approach. Perspectives from Africa hold that improving security is a challenge, especially creating a more seamless experience and staying ahead of evolving threats is a true test facing the sector in the period post 2020; balancing the traveller's safety with traveller experience will continue to define the challenge into the foreseeable future.

Respondents confirmed that as tourist spaces in exotic destinations become more popular with millions of tourists trouping, it becomes apparent that tourists are increasingly becoming easy targets of terrorism. The implication for emerging markets like Africa is that terrorism is now ubiquitous, as illustrated by a spike in terrorist incidences. Given the ever widening chasm between the political elites and the poor, fundamental different religious views and political opinions, these are fuelling terrorism irrespective of geographical location. Since time immemorial, tourism has been known as a peace sector. Another perspective is that whilst the end of WWII was generally interpreted as marking the dawn of political peace at global level and was hailed as a seed bed to nurture tourism development, it is increasingly being realised it was an illusion. To date global peace is becoming elusive because of indiscriminate acts of terrorism. Given the global publicity and media attention attendant to terrorist attacks on tourist destinations, the scourge dents the tourism phenomenon, especially for emerging tourism destinations whose safety and security systems are regarded as weak or inadequate. Indeed, the tourism phenomenon has been known to be resilient but the negative publicity associated with terrorist attacks adversely affect tourism trends and patterns. Terrorism has the potential to destroy tourism overnight despite its gigantic size.

The present day society is become heavily infested with terrorist groups who are increasingly targeting, attacking, kidnapping and killing international tourists (Stafford et al. 2002). Adeloye and Carr (2019) argue that terrorist attacks on tourists serve as unpleasant reminders of how fragile and vulnerable the tourism industry is to terrorism. The UNWTO (2018a, b) advocates for tourist destinations to be proactive and institute quick response or rescue strategies in the aftermath of an attack. Alongside this, tourist destinations should have in place destination recovery plans and marketing strategies to restore market confidence in the post attack period. Terrorism influences tourists' perceptions of risk and their resultant travel decisions.

In the twenty-first century the notorious terrorist groups threatening world peace and stability are the Islamic State, Hamas, Hezbollah, Boko Haram, Taliban, Al-Queda, and Al-Shabaab to mention a few. The tourism sector, economic growth and development of countries can be seriously threatened if tourist destinations increasingly become scenes of terrorist attacks. To this effect, tourist destinations need to invest in security protocols, which would put them in a stead to recover in a faster manner, provided the protocols are well created and implemented correctly (World Economic Forum 2015). Crisis protocols, recovery strategies, and strong emergency plans are indispensible for tourist destinations to recover fast and should become buzz words in future tourism development trajectories. Despite the resilience of the tourism sector, recurrent incidents of violence and terrorism at global level, increased insecurity and safety of tourists, as well as ruined perceptions deter potential tourists from fully and freely partaking in tourism. The scourge of terrorism imposes restrictions to visiting tourist destinations prone to attacks, henceforth matters of tourist safety and security are very critical when it comes to the future of the tourism industry.

Terrorism makes the tourism sector vulnerable and fragile making its future growth prediction uncertain (Abadie and Gardeazabal 2003). Conventional literature show that terrorism disrupts the entire tourism value chain where upon key stakeholders like travel agents would not actively promote tourist destinations perceived as being unsafe. Terrorist attacks have continually degraded and undermined the popularity of tourist destinations. In the aftermath of terrorist attacks, the tourism industry experiences significant down turn, the kidnapping of tourists by terrorist's network groups also frightens tourists away.

From Africa's viewpoint, terrorism's effects on tourism are multi-faceted: a decrease in the number of tourist arrivals, reduction in FDI, cost of reconstruction of tourist facilities, safety and security upgrades 
costs, and increased marketing costs to attract visitors. This is in line with what was established by Barth et al. (2006) that there is a very strong connection between terrorism and tourism, tourist sites which are targeted by terrorists have their social order and economic stability greatly shaken. The tourism sector is increasingly becoming a target of terrorists; the resonance being that the tourism sector is the main source of income of many countries, so by damaging it the core function of the economic basis of the nation stops working, destroying tourism attractions is the best way for the terrorists to get their message delivered through-out media coverage, thus getting the attention they need, and the tourism sector has not focused on security matters (Tarlow 2003). Tarlow (2003) emphasise that security plus service and value for money will become the basis for twenty-first century services. Terrorism encompasses the murder of high profile journalists, and media personalities which are covered by the international media contributing to the negative image of tourist destinations. Potential tourists see such cases as indicators of lack of safety; this also shows that the security system at global level is fragmented and not sufficient to ensure the security of citizens. Threats on global peace will remain a major issue hampering tourism growth, and stifle tourist destinations to realise full potential for foreign visitors and under utilisation of tourist attractions. In the absence of safety and security, tourism will not flourish. The effects of terrorism have destroyed tourist destinations brands in the tourism market.

\section{Conclusion and recommendations}

In conclusion, the current study contributes to literature by investigating the global tourism industry dynamics and their implications to emerging tourist destinations. The study examined fundamental shifts characterising the global tourism landscape since the end of WW2. These were identified as the formation of BRICS countries, ageing population, trophy hunting debate and terrorism. At the inception of tourism, boom factors influenced the growth of the industry, driven by the G7 member countries, however, as time went by, emerging markets increasingly became more significant, largely driven by the BRICS. Contemporary tourism dynamics framed as the constructs of BRICS, trophy hunting, ageing population and terrorism have been applied simultaneously to establish the extent to which they are impacting tourism growth projections from the perspectives of emerging markets. These have impacted on the trends of international tourism in a profound way. It is apparent that emerging markets are now in the front foot dictating the pace of tourism development. In light of such fundamental shifts, it is recommended that tourist destinations recalibrate their tourism product offerings so that they reflect the contemporary market dynamics. On the investment front, the emerging markets represent the future of the tourism sector, and finally in light of the devastating effects of terrorism, emerging tourist destinations should refine their terror responsive strategies.

Apart from the above, another area in need of attention is policy reform, in which immigration regulations and visa regimes should be constantly revised to strike a balance between screening travellers, balancing liberalising and softening the border control formalities to allow free flow of traffic but without compromising on the security and safety matters of tourists. Finally, marketing and promotion efforts need to be directed and focused on emerging markets and less on mature tourist regions since the former represent the future of the global tourism industry. This study therefore made a contribution in the specific areas of emerging markets, tourism senior market, Convention on International Trade in Endangered Species (CITES), and terrorism as key aspects that can make or break the global tourism industry in the twenty-first century.

This research responded to the need for continuous research on Africa's tourism sector and situate it in the global tourism industry (Naude and Saayman 2005; Christie and Crompton 2001; Rogerson and Visser 2011; Dieke 2013). To the best of the writer's knowledge, this study presents new knowledge from an emerging tourist region context regarding the dynamics obtaining in the global tourism environment and their subsequent implications. The current study was done in the context of Africa an emerging tourist region, with a less influential influence in the international tourism stage. Therefore, this study provides a significant addition to literature currently dominated by insights and perspectives from advanced societies like western tourism markets. 


\section{Compliance with ethical standards}

Ethical approval This research was carried out on respondents after full disclosure of the purpose and objectives of the study. Participants voluntarily consented to participate in the study. No minors nor vulnerable groups/individuals were involved as respondents during data collection. The study did not use unorthodox means of collecting data. There was no conflict of interest nor any envisaged commercial gain accruing to the researcher by undertaking the study. The manuscript was not submitted to any other journal neither is it under consideration in any other journal. The writer acknowledged ideas from other authoritative sources as far as possible. Information contained in the manuscript is not injurious to any organisation. In view of this, the research therefore complied with acceptable ethical standards.

\section{References}

Abadie, A., \& Gardeazabal, J. (2003). The economic costs of conflict. A case study of the Basque community. Retrieved July 10, 2019, from https://hks.Havad.edu/fs/aabadies/ eccp.pdf.

Abdou, D. M. S., \& Adawy, N. S. E. (2018). BRICS challenges: Economic position, tourism and environmental impacts. International Journal of Environmental Monitoring and Protection, 5(3), 64-72.

Adeloye, D., \& Carr, N. (2019). Terrorism and tourism recovery cases. A study of Tunisia and Egypt. In M. Mkono (Ed.), Positive tourism in Africa. London: Routledge, Taylor and Francis Group.

AfDB. (2016). African Development Bank. Africa. Tourism monitor: Sustainable tourism through innovation, entrepreneurship and technology.

Alen, E., Losada, N., \& Dominguez, T. (2015). The impact of ageing on the tourism industry: An approach to the senior tourist profile. Social Indicators Research, 127, 303-322.

Al-Shorman, A., Rawashdih, A., Oudat, A., \& Darabsih, F. (2016). Middle east political instability and Jordanas tourism. Journal of Tourism Research \& Hospitality, 5(1), 1000155. https://doi.org/10.4172/2324-8807.1000155.

Al-Tawfiqef, J. A., Zumlaad, A., \& Memis, Z. A. (2014). Travel implications of emerging coronaviruses: SARS and MERS-Covid. Travel Medicine and Infectious Diseases, 12(95), 422-428.

Alvarez, M. D., \& Campos, S. (2014). The influence of conflicts on country image and intention to visit: A study of Israel's image. Tourism Management, 40(92), 70-80.

Anton, C., Camarero, C., \& Laguma-Garcia, M. (2017). Towards a new appraisal of destination loyalty drivers: Satisfaction, visit intensity and tourist motivations. Current Issues in Tourism, 20(3), 238-260.

Badulesani, A., \& Rusu, S. (2009). The dynamics of the international tourism market. Recent developments and challenges. GeoJournal of Tourism and Geosites, 2(4), $145-152$.

Baker, J. (2010). Trophy hunting as sustainable use of wildlife resources in southern and Eastern Africa. Journal of Sustainable Tourism, 5(4), 306-321.
Barth, J., Li, T., McCarthy, D., Phumiwasang, T. \& Yago, G. (2006). Economic impacts of global terrorism: From Munich to Bali. Retrieved August, 2019, from https:// milkeninstitute.org/pdf/eco_impact_terrorism.pdf.

Batara, J. B. L., Manblanca, J., Kinaadman, K. M. D., \& Go, J. A. B. (2018). The effect of consumer innovativeness, perceived benefits, perceived risk and brand image in the decision to buy online. Recoletos Multidisciplinary Research Journal, 6(1), 56-63.

Batavia, C., Nelson, M. P., Darimont, C. C., Paquet, P. C., Ripple, W. J., \& Wallach, A. D. (2018). The elephant (head) in the room: A critical look at trophy hunting. Conservation Letters, 12, e12565.

Benediktsson, K., Lund, A. K., \& Huijbens, E. (2011). Inspired by Eruptions? Eyjafjallajokull and Icelandic tourism. Mobilities, 6(91), 77-84.

Bhatia, A. K. (2001). International tourism management. New Delhi: Sterling Publishers Private limited.

Bongkosh, N. R. (2006). Tsunami recovery: A case study of Thailand's tourism. Cornell Hotel and Restaurant Administration Quarterly, 47(4), 390-404.

Boniface, B., \& Cooper, C. (2001). World-wide destinations. The geography of travel and tourism. Oxford: ButterworthHeinemann.

Boyens, I. (2010). Rethinking townships tourism; towards responsible tourism development in South African townships. Development Southern Africa, 27(2), 273-287.

Booyens, I., \& Visser, G. (2010). Tourism small to medium enterprises development on the urban fringe: The case of Parys, South Africa. Urban Forum, 21(4), 367-385.

Buscher, B. (2013). Transforming the frontier: Peace parks and the politics of neoliberal conservation in Southern Africa. Durban and London: Duke University Press.

Callister, P. (2006). Are New Zealanders heading for old age richer, better educated and more likely to be employed? In J. Boston \& J. A. Davey (Eds.), Implications of population ageing. Opportunities and risks. Wellington: Institute of policy Studies.

Carothers, T., \& Young, R. (2011). Looking for help? Will rising democracies become international supporters?. Washington DC: Carnegie Endowment for International Peace.

Chalk, P. (1997). Grey area phenomena in Southeast Asia: Piracy, drug trafficking and political terrorism. Canberra Papers on Strategy and Defence, Number 123, Canberra (pp. 5).

Chiutsi, S., \& Saarinen, J. (2017). Local participation in transfrontier tourism: Case of Sengwe community in Great Limpopo Transfrontier conservation area, Zimbabwe. Development Southern Africa, 34(3), 260-275.

Christie, I. T., \& Crompton, D. E. (2001). Tourism in Africa. Africa region working series, number 12 . Washington DC: World Bank.

Christie, I., Fernandes, E., Messer, I. H., \& Twining-Ward, L. (2013). Overview: Tourism in Africa: Harnessing tourism for growth and improved livelihoods. Washington DC: The World Bank.

Cooper, C., Fletcher, J., Fyall, A., Gilbert, D., \& Wanhill, S. (2007). El Turism teoria y practica. Madrid: Sintesin.

Cooper, C., Fletcher, J., Gilbert, D., \& Wan Hill, S. (2008). Tourism principles and practice. England: Longman. 
Correia, A., Kozak, M., \& Ferradeira, J. (2013). From tourist motivations to tourist satisfaction. International Journal of Culture, Tourism and Hospitality Research, 7(94), 411-424.

Coulibary, B. (2018). Africa's alternative path to development, project syndicate, May 3. Retrieved July 10, 2020 from https://www.project-syndicate.org/commentary/africaindustry-information-smokesnacks-by-brahima-coulibay2018-05?Barrier=accesspaylog.

Debyser, A. (2014). The European Union and tourism: challenges and policy responses. European Parliament Research Service.

Diakite, B., Jian, M. B., Becklne, M., Duyle, L., Kerian, K., \& Samuel, B. (2020). Trends, opportunities and challenges of the tourism industry in the Republic of Guinea. Social Economic Geography, 5(1), 7-14. https://doi.org/10. 12691/seg-5-1-2.

Dieke, P. U. C. (2009). Africa in the global tourism economy: Trend; patterns, issues and future perspectives. The Harvard College Economics Review, 3(2), 9-15.

Dieke, P. U. C. (2013). Tourism in sub-Saharan Africa: Production-consumption-Nexus. Current Issues in Tourism, 16(7-8), 623-809.

Dieke, P. U. C. (2020). Tourism in Africa: Issues and prospects. In T. Baum \& A. Ndiuini (Eds.), Sustainable resources human management in tourism. Geographies of tourism and global change. Cham: Springer. https://doi.org/10. 1007/978-3-030-41735-2_2.

Donaldson, R. (2013). Conference tourism: What do we know about the business tourist in South Africa? African Journal for Physical Health Education, Recreation and Dance, 19(2), 24-38.

Donaldson, R., \& Ferreira, S. C. A. (2007). Crime, perceptions and touristic decision making: some empirical evidence and propects for the 2010 FIFA world cup. Politikon, 34(3), 353-371.

Donalsdson, R., \& Ferreira, S. C. A. (2009). Re-creating urban destination image: Opinions of foreign visitors to South Africa on safety and security. Urban Forum, 20(1), 1-18.

Fan, T., Pu, B., Powpaka, S., \& Hao, L. (2019). The impact of disaster of a national airline on the nation's tourism: An empirical investigation. Sustainability, 11(5), 1233.

Ferreira, S. L. A. (2004). Problem associated with tourism development in Southern Africa: The case of Transfrontier Conservation Areas. GeoJournal, 60(30), 301-310.

Ferreira, S. L. A. (2006). Communities and transfrontier parks in the southern African development community: The case of the Limpopo National Park, Mozambique. South African Geographical Journal, 88(2), 166-176.

Ferreira, S. L. A., Van De Merwe, I. J., \& Zietsmann, H. L. (2007). Natural resource base as predictor of growth and development in western Cape Province. Geography, 92(1), 25-40.

Furlong, M. (2006). Turning silver into gold. How to profit in the new boomer market place. New Jersey: Financial Time Press.

Gaetano, J. I. (2009). The 9/11 attacks - a study of Al Qaeda's US use of intelligence and counter intelligence. Studies in Conflict and Terrorism, 32(3), 171-187.
Giraldi, A. (2016). Understanding the motivation of repeat visitors to Rome. European Journal of Tourism Research, 13(1), 43-57.

Glover, P., \& Prideaux, B. (2009). Implications of population ageing for the development of tourism products and destinations. Journal of Vacation Marketing, 15(1), 25-37. https://doi.org/10.1177/1356766708098169

Goldin, I. (2010). Tourism and the G20. G20 Travel and Tourism Summit, 24 February, 2010.

Gossling, S., Scott, P., \& Hall, C. M. (2020). Pandemics, tourism and global change: A rapid assessment of Covid-19. Journal of Sustainable Tourism. https://doi.org/10.1080/ 0966982/2020/1758708.

Hapairai, P. M. B., Walters, G., \& Li, S. (2018). The effectiveness of ad-induced emotion in reducing tourist risk perceptions towards politically unstable destinations. Tourism Recreation Research, 43(4), 483-496.

Heimisdottir, P., Saeprsdottir, A. D., \& Gisladottir, G. (2019). The sublime attraction of active volcanoes: An exploration of tourists' experiences doing a long-distance hiking route in Iceland. Tourist Studies, 19(2), 258-275.

Hoffman, B. (1998). Inside terrorism. New York Times. Retrieved from http://NYtimes.com/book/first/h/hoffmanterrorism/htmal. Accessed 30 July 2020.

Hoogendorn, G., \& Fitchett, J. M. (2018). Exploring the climate sensitivity of tourists to South Africa through trip advisor reviews. South African Geographical Journal, 101(1), 91-109.

Hoogendorn, G., Grant, B., \& Fitchett, J. (2015). Towards green guest houses in South Africa: The case of Gauteng and Kwazulu-Natal. South African Geographical Journal, 97, 123-138.

Jaensson, J. E. (2014). Tourism development in sub-Saharan Africa, and a case of cooperation from Sweden. Conference Academy of World Business, Marketing and Management Conference, Dubai.

Jennings, G. R. (2005). Interviewing: A focus on qualitative techniques. In B. W. Ritchie, P. Burns, \& C. Palmer (Eds.), Tourism research methods (pp. 99-118). Wallingford: CABI.

Kavita, E., \& Saarinen, J. J. (2016). Tourism and rural community development in Namibia: Policy issues review. International Journal of Geography. https://doi.org/10. $11143 / 456331$.

Kester, J. G. C. (2003). International tourism in Africa. Tourism Economics, 9(2), 203-221.

Kongoley, P. S. (2015). The impact of ebola on the tourism and hospitality industry in Sierra Leone. International Journal of Scientific and Research Publications, 5(120), 542-550.

Krejciie, R., \& Morgan, D. (1970). Determining sample size for research activities. Educational and Psychological Measurement, 30(3), 607-610.

Kyyra, S, \& Rantala, O. (2016). Disoriented travellers or disoriented destination? Analysis of future travel trend studies for Visit Arctic Europe Project. Unpublished manuscript.

Langford, G., Weissenberg, A., \& Gasdua, M. (2019). US travel and hospitality outlook, Deloitte. Retrieved August 2, 2020 from https://www2.deloitte.com/content/dam/Deloitte/us/ Documents/consumer-business/us-consumer-2019-ustravel-and-hospitality-outlook.pdf 
Lockwood, A., \& Medlick, S. (2001). Tourism and hospitality in the 21st century. Routledge: Butterworth-Heinemann.

Maphanga, P. M., \& Henama, U. S. (2019). The tourism impact of Ebola in Africa: Lessons on crisis management. African Journal of Hospitality, Tourism and Leisure, 8(3), 1-13.

Maria-Irina, A. (2017). Tourism in the new Europe: trends, policies and challenges. In Proceedings of the international conference on business excellence, (Vol. 11(1)). https:// doi.org/10.1525/picbe-2017-0053.

Mbaiwa, J.E. (2008). Tourism development, rural livelihoods and conservation in the Okavango Delta, Botswana, unpublished doctoral dissertation. Department of Recreation, Park and Tourism Sciences, Texas $\mathrm{A}$ and $\mathrm{M}$ University.

Mbaiwa, J. (2018). Effects of the safari hunting tourism ban on rural livelihoods and wildlife conservation in Northern Botswana. The South African Geographical Journal, 100(1), 1-21.

Mbaiwa, J. E., Mbaiwa, T., \& Siphambe, G. (2019). The community based natural resource management programme in southern Africa-promise or peril? The case of Botswana. In M. Mkno (Ed.), Positive tourism in Africa. London: Routledge.

Mbaiwa, J. E., \& Stronza, A. L. (2010). The effects of tourism development on rural livelihoods in the Okavango Delta, Botswana. Journal of Sustainable Tourism, 18, 635-656.

Mertens, D. M. (2005). Research methods in education and psychology: Integrating diversity with quantitative and qualitative approaches ( 2 nd ed.). Thousand Oaks: Sage.

Miles, M., Huberman, A. M., \& Saldana, J. (2013). Qualitative data analysis: A method source-book. Thousand Oaks, CA: Sage.

Mkono, M. (2018). The age of digital activism in tourism: Evaluating the legacy and limitations of the Cecil antitrophy hunting movement. Journal of Sustainable Tourism, 26, 1-17.

Mkono, M. (2019). Positive tourism in Africa Resisting Afropessimism. In M. Mkono (Ed.), Positive tourism in Africa (1st ed.). London: CRC Press, Taylor \& Francis Group.

Mkono, M., Hughes, K., \& Echentille, S. (2020). Hero or villain? Responses to Greta Thunberg's activism and the implications for travel and tourism. Journal of Sustainable Tourism, 28, 2081-2098. https://doi.org/10.1080/ 09669582.2020 .1789157$.

Moore, W. R. (2010). The impact of climate change on Caribbean tourism industry. Current Issues in Tourism, 13(55), 495-505.

Musavengane, R. (2018). Toward pro-poor local economic development in Zimbabwe: The role of pro-poor tourism. African Journal of Hospitality, Tourism and Leisure, 7(1), $1-15$.

Musavengane, R., Siakwah, P., \& Leonard, L. (2019). Does the poor matter in pro-poor driven sub-Saharan African cities? Towards progressive and inclusive pro-poor tourism. International Journal of Tourism Cities, 5(3), 392-411.

Naude, W., \& Saayman, A. (2005). Determinants of tourist arrivals in Africa: A panel data regression analysis. Tourism Economcs, 11(3), 365-391.

Njerekai, C., \& Mabika, P. (2016). A review of the global trophy hunting procedures and processes with illustrations from
Zimbabwe. African Journal of Hospitality, Tourism and Leisure, 5(1), 1-15.

Nyahunzvi, D. K. (2015). Negotiating livelihoods among Chivi curio traders in a depressed Zimbabwe tourism trading environment. Anatolia: An International Journal of Tourism and Hospitality Research, 26(3), 397-407.

OECD. (2018a). Mega trends shaping the future of tourism. Tourism Trends and policies, (pp. 61-92).

OECD. (2018b). OECD economic outlook (Vol. 2018(2)). Paris: OECD Publishing.

OECD. (2020). Tourism trends and policies. Policy Highlights.

Page, J. (2018). The road not take: Structural change in Africa. Reconsidered. In Foresight Africa: Top promotions for the continent in 2018.

Pandy, W. R. (2017). Tourism enterprises and climate change: Some research imperatives. African Journal of Hospitality, Tourism and Leisure, 6(4), 1-18.

Paraskevasa, A., \& Arendell, B. (2007). A strategic framework for terrorism prevention and mitigation in tourism destinations. Tourism Management, 28, 1560-1573.

Patterson, I. (2006). Growing older: Tourism and leisure behaviour of older adults. Cambridge: Cabi.

Pop, I. (2014). The role of tourism in the economies of BRICS countries-knowledge Horvas. Economics, 6, 136-141.

Prideaux, B., Coghlan, A., \& Mckercher, B. (2009). Identifying indicators to measure tourists' views on climate change. Paper presented at CAUTHE 2009 conference: See change: Tourism and hospitality in a dynamic world. Perth: Curtin University of Technology.

Prideaux, B., Crosswell, M., \& Ng, W. Y. (2000). Norfolk island visitor survey. Cairns: James Cook University.

Qui, W., Chu, C., Mao, A., \& Wu, J. (2018). The impacts on health, society and economics of SARS and H7N9 Outbreaks in China: A case comparison study. Journal of Environmental and Public Health. https://doi.org/10.1155/ 2018/2710185.

Rogerson, C. M. (2011). Youth tourism in Africa: Evidence from South Africa. Tourism Analysis, 16, 105-120.

Rogerson, C. M. (2013). Urban tourism, economic regeneration and inclusion. Evidence from South Africa. Local Economy, 28(2), 186-200.

Rogerson, C. M. (2014). Informal sector business tourism and pro-poor tourism: Africa's migrant entrepreneur. Mediterranean Journal of Social Sciences, 5(16), 153-161.

Rogerson, C. M., \& Visser, G. (2011). African tourism geographies: Existing paths and new directions. Tijdschrift voor Economische. En sociale Geografe, 102(2), 251-259.

Rogerson, C. M., \& Visser, G. (2014a). A decade of progress in African urban tourism scholarship. Urban Forum, 25, 407-417.

Rogerson, C. M., \& Visser, G. (2014b). Reframing place-based economic development in South Africa. The example of local economic development. Bulletin of Geography: Socio-Economic Series, 24, 203-218.

Saarinen, J. (2018). Beyond growth thinking: the need to revisit sustainable development in tourism. Tourism Geography, 20(2), 337-340.

Saarinen, J., Becker, F. O., Manwa, H., \& Wilson, D. (2009). Sustainable tourism in southern Africa: Local communities and natural resources in transition. Bristol: Channel View Publications. 
Saldana, J. (2013). The coding manual for qualitative researches, Number 14. Thousand Oaks, CA: Sage.

Salt, B. (2003). Baby boomer cultre gets its comeuppance. Review-Institute of Public Affairs, 55(2), 10.

Scholtz, M., \& Slabbert, E. (2016). The relevance of the tangible and intangible social impacts of tourism on selected Southern African countries. Journal of Tourism and Cultural Change. https://doi.org/10.1080/1476682.2015. 1031796.

Schroder, A., \& Widman, T. (2007). Demographic change and its impact on the travel industry: Oldies-nothing but goldies? In R. Conrady \& M. Buck (Eds.), Trends and issues in global tourism (pp. 3-17). Berlin: Springer.

Schubert, S. F., Juan, G. B., \& Wiston, A. R. (2011). The impacts of international tourism demand on economic growth of small economies dependent on tourism. Tourism Management, 32(2), 377-385.

Schuurman, B. (2019). Topics in terrorism research: reviewing trends and gaps, 2007-2016. Critical Studies on Terrorism, 12(30), 463-480.

Scott, D., Gossling, S., \& Hall, C. M. (2012). International tourism and climate change. Wiley Inter Disciplinary Reviews: Climate Change. https://doi.org/10.1002/wcc. 165.

Signe, L. (2018). Africa's tourism potential: Trends, drivers, opportunities, and strategies. Africa Growth Initiatives at Brookings. Retrieved August 18, 2020 from https://www. brookings.edu/wp-content/uploads/2018/12/Africastourism-potential_LaundryShne.pdf.

Slabbert, E., \& De Plussis, E. (2013). Do socio-demographic factors influence the travel behaviour of visitors to naturebased tourism products in South Africa? African Journal for Physical Health Education, Recreation and Dance, 19(3), 639-660.

Song, R., \& Lin, V. S. (2010). Impacts of the financial and economic crisis on tourism in Asia. Journal of Travel Research, 49(1), 16-30.

Spenceley, A. \& Meyer, D. (2017). Tourism and poverty reduction: Principles and impacts in developing countries. Routeledge.

Stafford, G., Yu, L., \& Armoo, A. K. (2002). Crisis management and recovery: How hotels responded to terrorism. In Cornell hotel and restaurant administration quarterly. Washington, DC: Cornell University.

Stake, S., \& Torrance, H. (2005). Case study. In B. Somekh \& C. Lewin (Eds.), Research methodology in the social sciences (pp. 33-40). London: SAGE.

Steiner, C. (2017). Political instability, transnational tourist company and destination recovery in the Middle East after 9/11. Tourism and Hospitality Planning and Development, 4(3), 169-190.

Tang, J., Leelawat, N., Suppari, A., \& Imamura, F. (2020). An effect of Tsunami to hotel occupancy: A case of Phiket. Thailand. IOP Conference series: Earth and Environmental Science.

Tarlow, P. (2003). Taking a realistic look at tourism in a time of terrorism. USA Today Magazine, 131(2694), 52.

Thornhill, M., \& Martin, J. (2006). Ten industries that ageing boomers will transform. In L. M. Harris (Ed.), After sixty (pp. 151-165). Ithaca: Paramount.
Tichaawa, T. M. (2017). Business tourism in Africa: The case of Cameroon. Tourism Review International, 21(2), 181-192.

Tolkach, D., Chon, K. K. S., \& Xiao, H. (2016). Asia pacific tourism trends: Is the future ours to see? Asia Pacific Journal of Tourism Research, 21(10), 1071-1084. https:// doi.org/10.1080/10941665.2015.1118395.

UN. (2011). United Nations, Department of Economic and Social Affairs, Population Division. World population prospects: The 2010 revision. New York, NY

UNCTD. (2016). Economic development in Africa report: Debt dynamics and development finance in Africa. United Nations Publications. Sales number. E.11.D.3. New York and Geneva.

UNCTD. (2017). United nations conference on trade and development: Economic development in Africa-tourism for transformative and inclusive growth.

UNWTO. (2010). Understanding tourism: Basic glossary. Retrieved August 25, 2020 from http://cf.cdn.unwto.org/ sites/all/files/docpdf/glossaryenrev.pdf.

UNWTO. (2018a). United Nations World Tourism Organisation, World tourism barometre.

UNWTO. (2018b). UNWTO tourism highlights 2018 edition. Retrieved August 15, 2020 from https://www.unwto.org/ global/publications/unwto-tourism-highlights-2018.

UNWTO. (2019a). International tourism highlights 2019 edition. Retrieved August 15, 2020 from https://www.unwto. org/publication/international-tourism-highlights-2019edition.

UNWTO. (2019b). World tourism barometre (Vol. 17, Issue 4, Number 2019). https://doi.org/10.18111/ wtobarometreeng.

UNWTO. (2020). World tourism (Vol. 18, Issue 1). https://doi. org/10.18111/wtobarometreegn.

Veal, A. J. (2006). Research methods for leisure and tourism: A practical guide (3rd ed.). Pearson Education: Harlow.

Visser, G., \& Rogerson, C. M. (2004). Researching the South Africa tourism and development nexus. GeoJournal, 60(3), 201-215.

Wang, Y. S. (2009). The impact of crisis events and macroeconomic activity on tourism's international inbound tourism demand. Tourism Management, 30(1), 75-82.

Weaver, D., \& Oppermann, M. (2000). Tourism management. Milton: Wiley.

Weng, M. L. (2014). Restoring tourist confidence and travel intentions after disasters: Some insights from a rejoinder to a series of unfortunate events in Malaysian tourism. Current Issues in Tourism, 20(1), 38-42.

Weston, R., Guia, J., Mihalic, T., Prast, L., Blaslo, D., FerrerRoca, N., et al. (2019a). European tourism: Recent developments and future challenges. Technical Report. https:// doi.org/10.2861/705.

Weston, R., Guia, J., Mihhahic, T., Prats, L., Blasco, D., FerrerRoca, N., et al. (2019b). Research for TRAN committeeEuropeantourism: recent developments and future challenges, European Parliament, Policy Department.

World Bank. (2014). Tourism in Africa: Harnessing tourism for growth and improved livelihoods.

World Economic Forum (2015). Global competitiveness report 2015.

World Travel Market. (2012). Industry report. London: ExCel. 
Woyo, E. (2018). An assessment of brand Zimbabwe's competitiveness and attractiveness as a tourism destination. Unpublished $\mathrm{PhD}$ thesis, North-West University.

WTTC. (2017). The global summit 2017, Bangkok, Thailand. Retrieved August 16, 2020 from https://www.wttc.org/ events/summits/previous-summits/the-global-summit2017.

WTTC. (2018). Travel and tourism economic impact 2018. India: World Travel and Tourism Council

Zeng, B., Carter, R. W., \& De-Lacy, T. (2005). Short-term perturbations and tourism effects: The case of SARS in China. Current Issues in Tourism, 8(4), 306-322.

Zhao, H. (2011). BRICS. The engine of global economic growth. China Economic Times, March 25.
Zhou, Z. (2014). Southern Africa tourism industry; recent trends and future prospects. International Journal of Hospitality and Tourism Systems, 7(2), 71-80.

Zhou, Z. (2019). Tourism progress in the SADC region. Post colonial era milestones. In M. Mkono (Ed.), Positive tourism in Africa (1st ed.). London: CRC Press, Taylor \& Francis Group.

Znojek, B. (2012). From BRIC to BRICS: Developments in the cooperation of emerging economies. The Polish Institute of International Affairs (PISM), Bulletin Number 41, (258).

Publisher's Note Springer Nature remains neutral with regard to jurisdictional claims in published maps and institutional affiliations. 